\title{
TABLE OF CASES*
}

Access of Polish War Vessels to the Port of Danzig (1931) PCIJ Reports, Series A/B, No 43 (11

December 1931) (Permanent Court of International Justice)

Advanced Building Systems Pty Ltd v Ramset Fasteners (Aust) Pty Ltd [1998] HCA 19 (High

Court of Australia)

Altera Corporation v Clear Logic Inc 424 F.3d 1079 (9th Cir. 2005)

Anton Piller KG v Manufacturing Processes Ltd [1976] Ch 55 (High Court of Justice,

England)

Arbitral Award of 31 July 1989, Judgment, ICJ Reports 1991 (International Court of Justice)

Arsenal Football Club PLC v Matthew Reed [2001] RPC 46 (High Court of Justice,

England)

$16.08-16.11$

Arsenal Football Club PLC v Matthew Reed [2003] 1 All ER 137 (European Court of

Justice) $16.10-16.11$

Arsenal Football Club PLC v Matthew Reed [2003] Ch. 454 (European Court of Justice) $.16 .08,16.11$

Baker v Selden 101 US 99 (1879) (US Supreme Court) 9.13

Bayer Inc v Canada (Attorney General) [1998] 1 FC 553 (Evans J); [1999] 87 CPR (3d) 293

(Rothstein, Sexton and Stone JJA) (Canadian Federal Court of Appeal) .29 .06 $39.41-39.45$

Bayer AG v Schein Pharmaceuticals Inc, 301 F.3d 1306 (Fed. Cir. 2002) .29 .06

Biogen Inc v Medeva plc [1997] RPC 1 (UK House of Lords) .............................................2.2.14

Bobbs-Merrill Co.v Straus, 210 US 339 (1908) (US Supreme Court) .....................................6.23

Bollinger v Costa Brava Wine Co Ltd [1960] Ch 262 (High Court of Justice, England) .....22.22,

Brooktree Corp v Advanced Micro Devices Inc 977 F.2d 1555 (Fed.Cir. 1992)

Calvin Klein Inc v International Apparel Syndicate [1995] FSR 515 (High Court of Calcutta)

Canon v MGM [1999] RPC 117 (European Court of Justice) $16.15,16.18$

Catnic Components Ltd v Hill \& Smith Ltd [1982] RPC 183 (UK House of Lords) .29 .04

CCH Canadian Ltd v Law Society of Upper Canada [2004] 1 SCR 339 (Supreme Court of Canada) $10.07-10.08$

Certain German Interests in Polish Upper Silesia case (1926) PCIJ Reports, Series A, No 7

(25 May 1926) (Permanent Court of International Justice) .V.18

CFPH LLC's Patent Applications, re, [2005] EWHC 1589 (Patent Court, England) ..........27.20

* References are to paragraph numbers except where page numbers have been used for clarity and these are indicated in bold italic. 
Competence of Assembly regarding admission to the United Nations, Advisory Opinion, ICJ

Reports 1950 (International Court of Justice)

Computer Edge Pty Ltd v Apple Computer Inc (1986) 161 CLR 171 (High Court of

Australia)

Consorzio per la tutela del formaggio Gorgonzola v Kaserei Champignon Hofmeister GmbH \&

Co. KG and Eduard Bracharz GmbH (C-87/97) [1999] ECR I-1301 (European Court of Justice)

Daiquiri Rum Trademark [1969] RPC 600 (UK House of Lords) 16.12

De Pascale Claim (1961), 40 International Law Reports 250 (Italian - US Conciliation Commission)

Data Access v Powerflex Services Pty Ltd (1999) 45 IPR 353 (Federal Court of Australia) .10 .04

Desktop Marketing Systems Pty Ltd v Telstra Corporation Ltd (2002) 119 FCR 491

(Federal Court of Australia) 10.07

eBay Inc. v MercExchange, LLC, 547 U.S. 388 (2006) (US Supreme Court) .44 .04

Eco Mfg. LLC v Honeywell International Inc, 295 F. Supp. 2 d 854 (S.D.Ind. 2003) 15.17

Eden SAR1 v OHIM ECJ No T-305/04 (European Court of Justice) 15.28

Environmental Designs Ltd v Union Oil Co, 713 F.2d 693, 696 (Fed. Cir. 1983) .29 .04

Euthanasia Compositions/Michigan State University (2005)T866/01 (EPO Boards of Appeal)

Federal Republic of Germany and Kingdom of Denmark v Commission of the European Communities (C-465/02, C-466/02) [2005] ECR I-09115 (European Court of Justice) 22.04-22.06

Frontier between Turkey and Iraq (Turkey v Iraq) (1925) PCIJ Reports, Series B, No 12 (21

November 1925) (Permanent Court of International Justice)

GIs Committee v The Honourable Justice O'Connor [2000] FCA 1877 (Federal Court of Australia)

Grupo Gigante S.A de CV v Dallo \& Co Inc 391 F.3d 1088 ( $9^{\text {th }}$ Cir, 2005)

Henkel KGaA v Office for Harmonisation in the Internal Market (Trademarks and Designs) [2004] ECR I-05089 (European Court of Justice) 15.17

IceTV Pty Ltd v Nine Network Australia Pty Ltd [2009] HCA 14 (High Court of Australia)

Interpretation of Peace Treaties with Bulgaria, Hungary and Romania: Second Phase, Advisory

Opinion, ICJ Reports 1950 (International Court of Justice)

Kewanee Oil Co v Bicron Corp, 416 US 470 (1974) (US Supreme Court)

Kirin-Amgen Inc v Hoechst Marion Roussel Inc [2004] UKHL 46 (UK House of Lords) .29 .04

Koninklijke Philips Electronics NV v Remington Products Australia (2000) 100 FCR 90

(Federal Court of Australia)

Levi Strauss v Aird and Berlis Federal Court, 2006, FC 654, 30 May 2006 (Canada)

L.F.H. Neer and Pauline Neer (U.S.A.) v. United Mexican States (Neer Claim) (1926) 4 UNRIAA 60 (General Claims Commission) $41.33,41.35$

Linde AG (C-53/01) (European Court of Justice)

Mag Instrument Inc v Office for Harmonisation in the Internal Market (Trademarks and

Designs) (C-136/02) [2004] ECR I-9165 (European Court of Justice)

Madeyv Duke University 307 F.3d 1351 (Fed. Cir. 2002) .27 .54 
Mareva Compania Naviera SA v International Bulkcarriers [1975] 2 Lloyd's Reports 509

(Court of Appeal, England)

Merrell Dow Pharmaceuticals v Norton [1996] RPC 76, p. 89 (UK House of Lords) ..........27.24

Meyers Taylor Pty Ltd v Vicarr Industries Ltd (1977) 137 CLR 228 (High Court of

Australia)

Mondev International, Ltd v United States, Case No. ARB(AF)/99/2,(2002) Award

(International Centre for the Settlement of Investment Disputes)

$.41 .32,41.37$

MTD Equity Sdn Bhd and MTD Chile SA v Republic of Chile (2004) ICSID Case

No.ARB/01/7

Nelson, In re, 280 F.2d 172 (CCPA 1960)

Nichols v Universal Pictures Corp., 45 F.2d 119, 121 (2nd Cir. 1930)

Novartis/Transgenic Plant Systems (2000) G 1/98 (EPO Boards of

Appeal) .....

Nuclear Tests Case (Australia v. France), ICJ Reports 1974 (International Court of

Justice)

Opinion on Admission of a State to the United Nations, ICJ Reports 1948 (International

Court of Justice)

Plant Cells/Plant Genetic Systems (1995)T356/93 (EPO Boards of Appeal) .27 .69

Penife International Ltd v Comptroller-General of Patents, Trademarks and Designs [2004] RPC 37 (High Court, England)

Pension Benefit System Partnership (2001), T931/95 (EPO Boards of Appeal) .27 .14

Pfizer Corporation v Ministry of Health [1965] 1 All ER 450 (UK House of Lords) .31 .09

Polish Postal Service in Danzig, Advisory Opinion, PCIJ Reports, Series B, No. 11 (16 May

1925) (Permanent Court of International Justice)

Quality King v L'Anza, 523 US 135 (1998) (US Supreme Court) 6.23

Rado Uhren AG (C-55/01) [2003] ECR I-03161 (European Court of Justice) .15 .17

Revlon Inc v Cripps \& Lee [1980] FSR 85 (Supreme Court of Judicature, Court of Appeal

(Civil Division))

.16 .06

Robertson v Thomson Corporation [2006] 2 SCR 363 (Supreme Court of Canada) .10 .11

Rural Telephone Service Company Incorporated v Feist Publications Inc 957 F.2d 765

(10th Cir, 1992)

Saccharin Corp v Anglo-Continental Chemical Works Ltd (1900) 17 RPC 307 (High Court, England) .27 .46

Scandecor Developments AB v Scandecor Marketing and Others [2001] UKHL 21

(UK House of Lords)

Shield Mark BVv Joost Kist [2003] ECJ C-283/01 (European Court of Justice)

Spirits International Nvv The Registrar of Trade-marks 2006 FC 520, April 26, 2006

(Canadian Federal Court)

State Street Bank \& Trust Co v Signature Financial Group, 149 F.3d 1368 (Fed Cir, 1998)

Strijland, ex parte, 26 USPQ2d 1259 (Board of Patent Appeals and Inferences 1992) ..........25.04

Telstra Corporation Ltd v Phone Directories Company Pty Ltd [2010] FFCA 149

(Full Federal Court of Australia)

The Arbitral Award made by the King of Spain, ICJ Reports 1960 (International Court of Justice)

The Temple of Preah Vihear, ICJ Reports 1962 (International Court of Justice) ........................18

Toys 'R' Us v Akkaoui 40 USPQ92d (BNA) 1836 (N.D. Cal. 1996) 
Toys 'R' Us and Deere \& Co v MTD Products Inc 41 F.3d 39 (2d Cir. 1994) 16.46

Transgenic animals/Harvard, (2004) T315/03 (EPO Boards of Appeal) $.27 .54,27.63$

Universal Music Australia Pty Ltd v Sharman License Holdings Ltd (2005) 65 IPR 289

(Federal Court of Australia) 9.13

USA - France Air Transport Services Arbitration (1963), 38 International Law Reports 243

(Arbitral Tribunal) ..I.34

US - Section 337 of the Tariff Act of 1930 (1989) Report by the Panel (L/6439 - 36S/345) (GATT Panel) .3.32-3.34, 3.45, 3.73-3.75, 3.77, 27.42, 27.54, 27.86

Waterman v Mackenzie, 138 US 252 (1890) (US Supreme Court) 28.19

Western Sahara, Advisory Opinion, ICJ Reports 1975 (International Court of Justice) .2 .18

Winward Industries Inc. (C-54/01) (European Court of Justice) 15.17

Whirlpool Trademark [1997] FSR 905 (Supreme Court, India) 16.31 